\title{
Editorial
}

\section{O Ibri e a Revista Brasileira de Política Internacional: tradição, continuidade e renovação}

\author{
ANTÔNIO CARLOS LESSA* \\ PAULO ROBERTO DE ALMEIDA**
}

Doze anos atrás, um pequeno grupo baseado em Brasília, formado por acadêmicos, diplomatas e outras pessoas interessadas em temas de política internacional, empreendia a tarefa de resgatar de um limbo inesperado (e do provável desaparecimento) a mais antiga revista precipuamente voltada para a área de relações internacionais existente no Brasil: esta mesma que o leitor tem em mãos neste momento.

A Revista Brasileira de Política Internacional era publicada de maneira contínua desde 1958, por iniciativa do Instituto Brasileiro de Relações Internacionais que, em sua primeira encarnação, tinha sido fundado no Rio de Janeiro em 1954, por um grupo pioneiro de acadêmicos, de diplomatas e de homens públicos e empresários, identificados com o debate que então se adensava em torno das grandes questões nacionais e internacionais.

Entre esses homens, interessados em reforçar entre nós o conhecimento da política mundial de modo a melhor situar o Brasil em face dos desafios do sistema internacional, estava Cleantho de Paiva Leite, fundador do primeiro Ibri e, durante muitos anos, editor, organizador, promotor, divulgador e principal financiador da Revista Brasileira de Política Internacional, de quem ela ficou orfã em 1992, após ter servido durante 35 anos como principal canal de debate entre nós em torno dos temas de relações internacionais e de política externa do Brasil. O novo grupo de acadêmicos e de diplomatas decidiu então retomar em Brasília, sob a responsabilidade de um novo Ibri, reconstituído para tal finalidade, a publicação da Revista Brasileira de Política Internacional, o que foi feito desde 1993, sem quebra, portanto, da continuidade editorial. Olhando retrospectivamente o itinerário percorrido, desde 1954, mas também a partir de 1992, podemos legitimamente orgulharmo-nos de, não apenas termos conseguido manter os nobres objetivos em torno dos quais tinha sido fundado o primeiro Ibri, mas de também

\footnotetext{
* Professor adjunto do Instituto de Relações Internacionais da Universidade de Brasília (UnB) e editor da Revista Brasileira de Política Internacional - RBPI.

** Diplomata de carreira e editor adjunto da Revista Brasileira de Política Internacional - RBPI.
} 
termos logrado preservar uma memória histórica e documental inigualável sobre as relações exteriores do Brasil e sobre a política internacional.

Neste ano de 2004, quando comemoramos o primeiro meio século de existência do Ibri e inauguramos uma nova etapa da vida brasiliense da Revista Brasileira de Política Internacional, desejamos partilhar com os leitores e colaboradores ativos da revista e do Instituto este justo orgulho pelo sucesso do empreendimento até aqui conduzido e augurar que os esforços dispendidos por todos possam ser reconhecidos pela comunidade brasileira de internacionalistas. Cabe registrar aqui uma homenagem especial ao embaixador Sérgio Guarischi Bath (então Diretor do Instituto Rio Branco do MRE), pelo apoio na transferência do Ibri para Brasília, bem como ao professor Amado Luiz Cervo, por ter assegurado de maneira exemplar e com alto sentido acadêmico e profissional a editoria da Revista Brasileira de Política Internacional nos primeiros onze anos de sua etapa brasiliense.

A futura comemoração dos primeiros cinquenta anos desta revista coincidirá, em 2008, com os dois séculos da transferência da corte portuguesa para o Rio de Janeiro, o que representou, igualmente, o início da formulação, da tomada de decisão e da condução das relações exteriores do Brasil a partir do próprio "Brasil" (naquela conjuntura, é verdade, ainda uma simples colônia, mas convertido, sete anos após, em "reino unido" e, em mais sete anos, em país independente). Muito ainda temos a dizer sobre o passado diplomático, sobre nossa atual política exterior e também, por que não?, sobre os caminhos futuros de nossas relações internacionais. A Revista Brasileira de Política Internacional continuará assegurando, temos certeza, altos padrões acadêmicos na análise dessas realidades, assim como no debate de qualidade sobre todas essas questões.

Junho de 2004. 